\title{
EFFECT OF GROWTH HORMONE THERAPY IN CHILDREN WITH PRADER-WILLI SYNDROME - OUR FIRST EXPERIENCES
}

\begin{abstract}
Gordana Stipančić $c^{1,2}$, Marija Požgaj Šepec ${ }^{2}$ and Lavinia La Grasta Sabolićc
${ }^{1}$ School of Dental Medicine, University of Zagreb, Zagreb, Croatia;

${ }^{2}$ Department of Pediatrics, Sestre milosrdnice University Hospital Centre, Zagreb, Croatia

SUMMARY - Prader-Willi syndrome (PWS) is the most common cause of morbid obesity in childhood.It is the consequence of the lack of expression of genes on the paternally inherited 15q11.2q13 region. Hyperphagia, obesity, short stature, psychomotor retardation and deterioration of behavior predominate in clinical presentation. Recombinant human growth hormone (rhGH) therapy, along with restriction of caloric intake, has become the mainstay in the management of PWS patients. Anthropometric parameters (height, body mass index (BMI)), therapy effect on carbohydrate and lipid metabolism, and occurrence of side effects were monitored in four children with PWS treated with $\mathrm{rhGH}$ for $\geq 2$ years at doses of up to $1 \mathrm{mg} / \mathrm{m}^{2} /$ day. During the follow-up, the height standard deviation score (SDS) increased in comparison with baseline values, and after $\geq 2$ years of treatment with rhGH it was within the reference range for the general children population. BMI SDS decreased after the first year of treatment, but thereafter increased again; still, the level of BMI SDS was much better in comparison with most children with PWS of the same age and gender. RhGH therapy had no negative effect on glucose and lipid metabolism, nor caused any other adverse effect. Therapy including a customized diet for PWS, along with rhGH therapy, provided a satisfactory growth rate and prevented development of morbid obesity without side effects. This treatment approach would ensure transition of a greater number of PWS patients into adult care, where the multidisciplinary approach in care should be continued.
\end{abstract}

Key words: Prader-Willi syndrome; Obesity, morbid; Human growth hormone - therapeutic use; Paternal inheritance; Energy intake

\section{Introduction}

Prader-Willi syndrome (PWS, OMIM 176279) is the most common cause of severe obesity in early childhood, and was first described by A. Prader, A. Lambhart and H. Willi in $1956^{1}$. PWS is the result of a genetic disorder caused by the lack of expression of genes on the paternally inherited 15q11.2-q13 region ${ }^{2}$.

The basic clinical characteristics include reduced muscle tone, which starts during intrauterine develop-

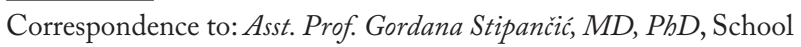
of Dental Medicine, University of Zagreb and Department of Pediatrics, Sestre milosrdnice University Hospital Centre, Vinogradska c. 29, HR-10000 Zagreb, Croatia

E-mail: gordana.stipancic@zg.t-com.hr

Received February 6, 2018, accepted March 15, 2018 ment and causes decreased fetal movements. In newborns and infants, hypotonia disrupts feeding and weight gain. However, feeding difficulties cease soon and excessive food intake develops, leading to morbid obesity. Obesity is accompanied by changes in the body composition, with increased body fat tissue and concomitant reduced amount of muscle mass. Despite obesity, these children do not grow properly and stay short; sexual development is absent and psychomotor development is retarded as well ${ }^{3}$. Most PWS patients have mild intellectual retardation with an average intelligence quotient (IQ) of 61, within a range of 40-1034.

Individuals with PWS have a characteristic dysmorphic phenotype, i.e. narrow bifrontal diameter, 
short eye slits and thin upper lip. Small hands and feet are predominant; hair, eyes and skin are often lighter than in other family members ${ }^{5}$.

DNA methylation test will determine the critical genetic region inherited exclusively from the mother and thereby confirm the diagnosis in $99 \%$ of patients. There are three main genetic mechanisms responsible for the development of PWS. In 65\%-75\% of cases, the cause is a deletion of the father's chromosome in the $15 \mathrm{q} 11-\mathrm{q} 13$ region, $20 \%-30 \%$ of patients will have maternal uniparental disomy of chromosome 15 , and a defect in the region that controls the imprinting process is responsible in only $1 \%-3 \%$ of patients ${ }^{6,7}$. Genetic analysis is essential for confirmation of the disease in all patients, especially in those who have not yet developed clinical characteristics of the disease or display atypical features. Early confirmation of the diagnosis, usually during the workup for neonatal hypotonia, is an opportunity to implement all treatment options available as early as possible . $^{2}$

The incidence of the disease is difficult to determine, however, based on data from the European countries it ranges from 1:10,000 to 1: 30,000 live births, with a prevalence in the general population of 1:50,000. Today, there are 350,000-400,000 affected individuals worldwide. An increase in the incidence is expected, as uniparental disomy is more common in older mothers. The mortality rate among affected individuals at the age of 6-56 years is $3 \%$ per year, as opposed to $0.14 \%$ in the general population ${ }^{9,10}$.

Overweight in otherwise healthy children during the growth period results in normal final height, frequently above the genetic potential and midparental height. Despite being overweight, children with PWS lag behind in growth and end up short. Consequently, growth hormone $(\mathrm{GH})$ secretion is decreased and insulin-like growth factor (IGF 1) ranges are within the normal limits. The mean final height is below midparental height; in males, it amounts to $161.6 \pm 8.1 \mathrm{~cm}$ $(-2.4$ standard deviation score, SDS $)$ and in females to $150.2 \pm 5.5 \mathrm{~cm}(-2.5 \mathrm{SDS})^{11}$. Short stature despite obesity, body composition with predomination of fat tissue, low IGF 1 levels, poor response of GH to pharmacological GH stimulation tests and decreased spontaneous $\mathrm{GH}$ secretion during $24 \mathrm{~h}$ clearly indicate $\mathrm{GH}$ deficiency ${ }^{12}$. As a GH deficit is present in $80 \%$ of those affected, testing before recombinant human growth hormone $(\mathrm{rhGH})$ therapy is not required and only
IGF 1 levels need to be evaluated, serving as useful indicators of the patient compliance to therapy and his/her GH sensitivity ${ }^{7,12}$. Besides GH deficiency, absence of the pubertal growth spurt due to hypogonadism or hypothyroidism can also contribute to the development of short stature.

In the late 1990s, randomized controlled studies confirmed the positive effect of rhGH therapy on the course of PWS. This therapy accelerated growth and improved final height, increased the amount of muscle mass and muscle tone, and thereby muscular strength, and the capacity for physical activity. The portion of fat tissue was decreased and respiratory function improved, while positive behavioral changes were also noted $^{13,14}$. Based on this, the US Food and Drug Administration (FDA) approved the use of $\mathrm{rhGH}$ in PWS children with short stature in the USA in 2000, and the European Medicines Agency (EMA) approved its application, indenpendently of height, in Europe in 2002, with the intention to improve body composition. Thereby, rhGH therapy has become a standard in the management of PWS children in developed countries.

Hypothalamic dysfunction not only causes pituitary hormone deficiency, but also other features of PWS such as unstable temperature, high threshold for pain, and inability to induce vomiting. These features make it more difficult to diagnose acute illnesses. Particular caution is needed with binge eating, which may cause choking, as well as stomach dilatation with necrosis and perforation ${ }^{8}$.

Two deaths of our PWS patients in adolescence were a strong motivation to improve the outcome of the disease. Thus, we were the first in Croatia to apply rhGH in our patients in 2009. Until now, seven children have been included in the treatment, four of which have been followed up for $\geq 2$ years. By presenting the results, we want to draw attention of a wider medical public in Croatia to the possibilities of such treatment for this rare disease.

\section{Patients and Methods}

We conducted a retrospective analysis of patient histories of four PWS patients, one girl and three boys, who were and/or are currently treated with $\mathrm{rhGH}$ due to PWS. The genetic basis of the disease was confirmed in all patients. In the female patient, blood samples 
from the biological parents were unavailable; therefore, the diagnosis was made only by methylation test; in the other three patients, molecular testing confirmed microdeletion or uniparental disomy. Additionally, each patient was karyotyped from a sample of peripheral blood.

Immediately before rhGH therapy had been introduced, as well as during the follow-up, anthropometric measurements were performed in all patients; height was measured by the Harpenden stadiometer and body weight by calibrated scales with a lever. All initially measured height and body mass index (BMI) values in $\mathrm{kg} / \mathrm{m}^{2}$ (according to the formula: body weight in $\mathrm{kg}$ divided by height in $\mathrm{m}^{2}$ ), as well as those measured during the follow-up were compared with the standardized National Center for Health Statistics (NCHS) growth curve for the general population of children $^{15}$. In order to unite the values for both genders, we expressed the $z$-values (SDS) for height and BMI according to the NCHS curve at baseline, after 12 months, and at the last check-up.

At the beginning of treatment, three children were in prepuberty, the girl with breast Tanner stage $<2$, and the boys with testicles $<4 \mathrm{~mL}$ volume. One boy was in early spontaneous puberty, with testicles $6 \mathrm{~mL}$ by Prader and genital development stage 2 by Tanner and Whitehouse ${ }^{16}$.

The doses of rhGH during the treatment were up to $1 \mathrm{mg} / \mathrm{m}^{2}$, i.e. $0.035 \mathrm{mg} / \mathrm{kg} /$ day (Genotropin; Pfizer Inc., Zagreb, Croatia), and were gradually increased during the first 6-9 months, along with evaluation of IGF 1 levels. From that point on, the doses of rhGH were adjusted every 6 months according to the body surface area and IGF 1 levels.

Fasting blood glucose, insulin level, lipid profile, free thyroxine (fT4), thyroid-stimulating hormone (TSH) and adrenocorticotropic hormone (ACTH) were determined using classic techniques at the beginning of treatment and every 6-12 months thereafter. A low-dose ACTH test was performed at the beginning of treatment in order to evaluate adrenal function.

The homeostatic model assessment of insulin resistance (HOMA-IR) index was calculated using the classic formula: product of fasting blood glucose $(\mathrm{mmol} / \mathrm{L})$ and fasting insulin level $(\mathrm{mIU} / \mathrm{mL})$ divided by 22.5 .

Before therapy introduction and in the first year of treatment, each child underwent all-night polysomno- graphic recording and had his/her apnea/hypopnea index (AHI) determined. Before introducing rhGH therapy, as well as once annually or as needed thereafter, radiologic evaluation of the spine was performed to see progression of the possibly present scoliosis. Otorhinolaryngoscopic examination evaluated the tonsils and adenoids and indicated adenotonsillectomy when necessary.

The aim of the research was to investigate the effect of $\mathrm{rhGH}$ on anthropometric parameters, height and $\mathrm{BMI}$, and evaluate the safety of therapy by observing IGF 1 levels, glucose homeostasis and lipid profile. Levels and secretion of pituitary and peripheral endocrine hormones, as well as the occurrence of adverse effects were also monitored.

Before therapy introduction, the parents signed an informed consent form, which included information on the benefits and possible risks of the treatment.

\section{Results}

Starting in 2009, we have been treating four PWS patients with rhGH for $\geq 24$ (range 36 to 96) months. Their most relevant clinical characteristics are shown in Table 1. All children were term born; in two of them, delivery was performed by cesarean section due to breech position and threatening asphyxia. In two children, birth weight and length were within the reference range for gestational age, and the other two were small for gestational age. In all children, hypotonia was recorded immediately after birth, leading to diagnostic workup and confirmation of the diagnosis of PWS in three children in the first year of life. In the fourth child, the oldest in the group, diagnostic workup was done at the age of 4 , when it became available in our country. All children were included in a habilitation program due to hypotonia and motor retardation. Three children have cognitive development retardation with IQ between 57 and 71, and the fourth child has IQ 83 and attends second grade of the regular elementary education program.

All patients had normal karyotypes. In two patients, PWS was caused by deletion of the 15q11-q13 region, and in one patient by maternal uniparental disomy of the same region. In the female patient, the diagnosis was made only by methylation test, confirming the lack of expression of the father's allele in the $15 \mathrm{q} 11-\mathrm{q} 13$ region because blood samples from the biological parents were unavailable. 
Table 1. Clinical and anthropometric characteristics of children with Prader-Willi syndrome treated with recombinant buman growth hormone

\begin{tabular}{|c|c|c|c|c|}
\hline Patient & 1 & 2 & 3 & 4 \\
\hline Age at therapy initiation (yrs) & 10.5 & 7.2 & 2.8 & 5.5 \\
\hline Gender $(\mathrm{M} / \mathrm{F})$ & $\mathrm{M}$ & M & $\mathrm{F}$ & M \\
\hline $\begin{array}{l}\text { Karyotype } \\
\text { genotype/dg }\end{array}$ & $\begin{array}{l}46 \mathrm{XY} \\
\mathrm{UPD} / 3\end{array}$ & $\begin{array}{l}46 \mathrm{XY} \\
\mathrm{Del} / 1\end{array}$ & $\begin{array}{l}46 \mathrm{XX} \\
\mathrm{MT} / 1\end{array}$ & $\begin{array}{l}46 \mathrm{XY} \\
\mathrm{Del} / 1\end{array}$ \\
\hline $\begin{array}{l}\text { Delivery/weeks } \\
\text { Birth weight/length }(\mathrm{kg} / \mathrm{cm})\end{array}$ & $\begin{array}{ll}39 \\
3.07 / 48 \\
\end{array}$ & \begin{tabular}{|l|}
40 \\
$2.47 / 46$ \\
\end{tabular} & $\begin{array}{l}40 \\
3.5 / 52 \\
\end{array}$ & $\begin{array}{ll}40 \\
2.81 / 47\end{array}$ \\
\hline Hypotonia/feeding difficulties & + & + & + & + \\
\hline Psychomotor retardation, IQ & + & + & + & $\begin{array}{l}\varnothing \\
83\end{array}$ \\
\hline $\begin{array}{l}\text { MPH }(\mathrm{cm}) \\
\mathrm{c} / \mathrm{SDS}\end{array}$ & \begin{tabular}{|l|}
185 \\
$94 / 1.55$
\end{tabular} & \begin{tabular}{|l|l}
188 \\
$98 / 2.1$
\end{tabular} & $\varnothing$ & \begin{tabular}{|l|}
170 \\
$26 /-0.63$
\end{tabular} \\
\hline $\begin{array}{l}\text { Height }(\mathrm{cm}), \mathrm{c} / \mathrm{SDS} \\
\text { Therapy initiation } \\
12 \text { months } \\
\text { Currently }\end{array}$ & \begin{tabular}{|l|}
$135.6 ; 26.6 ;-\mathbf{0 . 6 2}$ \\
$145.2 ; 51.3 ; \mathbf{0 . 0 3}$ \\
$172.7 ; 44.3 ;-\mathbf{0 . 1 4}$ \\
\end{tabular} & $\begin{array}{l}\text { 115.8/; 13.8; -1.1 } \\
\text { 128.9; 56.7; } \mathbf{0 . 1 7} \\
\text { 164.1; } 25.6 ;-\mathbf{0 . 6 5}\end{array}$ & \begin{tabular}{|l}
$84.2 ; 2.2 ;-\mathbf{2 . 0}$ \\
$93.1 ; 6.4 ;-\mathbf{1 . 5}$ \\
$126.3 ; 20 ;-\mathbf{0 . 8 4}$ \\
\end{tabular} & $\begin{array}{l}\text { 99.3; -2.4 } \\
\text { 108; } 3.7 ;-\mathbf{1 . 8} \\
120 ; 6.9 \text { c. } \mathbf{- 1 . 4} \\
\end{array}$ \\
\hline $\begin{array}{l}\text { BMI c/SDS } \\
\text { Therapy initiation } \\
12 \text { months } \\
\text { Currently }\end{array}$ & $\begin{array}{l}26.8 ; 99.7 / 2.8 \\
25.6 ; 99.6 / 2.6 \\
26.5 ; 95.7 / 1.7 \\
\end{array}$ & $\begin{array}{l}26.1 ; 99.9 / 3.6 \\
20.1 ; 97.4 / 1.9 \\
25.8 ; 97.3 / 1.9 \\
\end{array}$ & $\begin{array}{l}17.2 ; 83 / \mathbf{0 . 9 6} \\
15.8 ; 52.5 / \mathbf{0 . 0} \\
18.9 ; 85 / \mathbf{1 . 0 6} \\
\end{array}$ & \begin{tabular}{|l}
$17.8 ; 94 / \mathbf{1 . 5 6}$ \\
$15.5 ; 51.0 / \mathbf{0 . 0}$ \\
$18.0 ; 87.5 / \mathbf{1 . 1 5}$ \\
\end{tabular} \\
\hline Therapy duration (yrs) & 6 & 8 & 6.5 & 3 \\
\hline
\end{tabular}

$\mathrm{M}=$ male; $\mathrm{F}$ = female; $\mathrm{UPD}=$ uniparental disomy; Del = deletion; $\mathrm{MT}=$ methylation test; $\mathrm{MPH}=$ midparental height; $\mathrm{IQ}=$ intelligence quotient; $\mathrm{c} / \mathrm{SDS})=$ percentile/standard deviation score

Initial problems with feeding were present in two children. The period of hyperphagia began between the second and fourth year of life in all children. The parents of the children that were diagnosed as infants were given instructions about the dietary regimen required.

RhGH therapy started at the age between 2.8 and 10.5 years. Three children were in prepuberty and one boy in spontaneous early puberty, but after two years further progression of puberty was lacking. In one boy, spontaneous early puberty began during treatment at the age of 9.5, and is still progressing. At the point of introduction of $\mathrm{rhGH}$ therapy, the patient height SDS was between -0.62 and -2.5 . In the children that were not of short stature, previous follow up showed growth retardation. The three children whose parents' heights were known had a height SDS lower by 1.8-3.2 than the midparental height (Table 1).

The growth hormone stimulation test was not performed before the introduction of rhGH; only IGF 1 was measured for the purpose of further follow up. Af- ter 3 to 8 years of treatment, there was an increase in height SDS between 0.45 and 1.12, and therapy is still ongoing in three children. After 8 years of treatment, one boy attained his final height of $172.7 \mathrm{~cm}, 44.3 \mathrm{c}$, -0.14 SDS, which was still below his midparental height (185 cm, 94 c, 1.55 SDS). He started rhGH therapy relatively late, at the age of 10.5 years, and he also developed early spontaneous puberty (Fig. 1, Table 1).

At initiation of rhGH therapy, two patients had $\mathrm{BMI}$ in the range of severe obesity (BMI $>99 \mathrm{c}$ ), one patient's BMI was in the range of overweight (BMI $>85$ c but $<95$ c), and one child had BMI of $<85$ c for age and gender, which is consistent with normal weight. After the first year of treatment, there was a significant BMI decrease in all children, followed by its gradual increase. However, at this point of treatment, which has been administered for 3 and 8 years, BMI is still better in three children; in the fourth child, there has been a BMI SDS increase by 0.1 after 6.5 years of treatment, but the absolute BMI value is in the 85 per- 


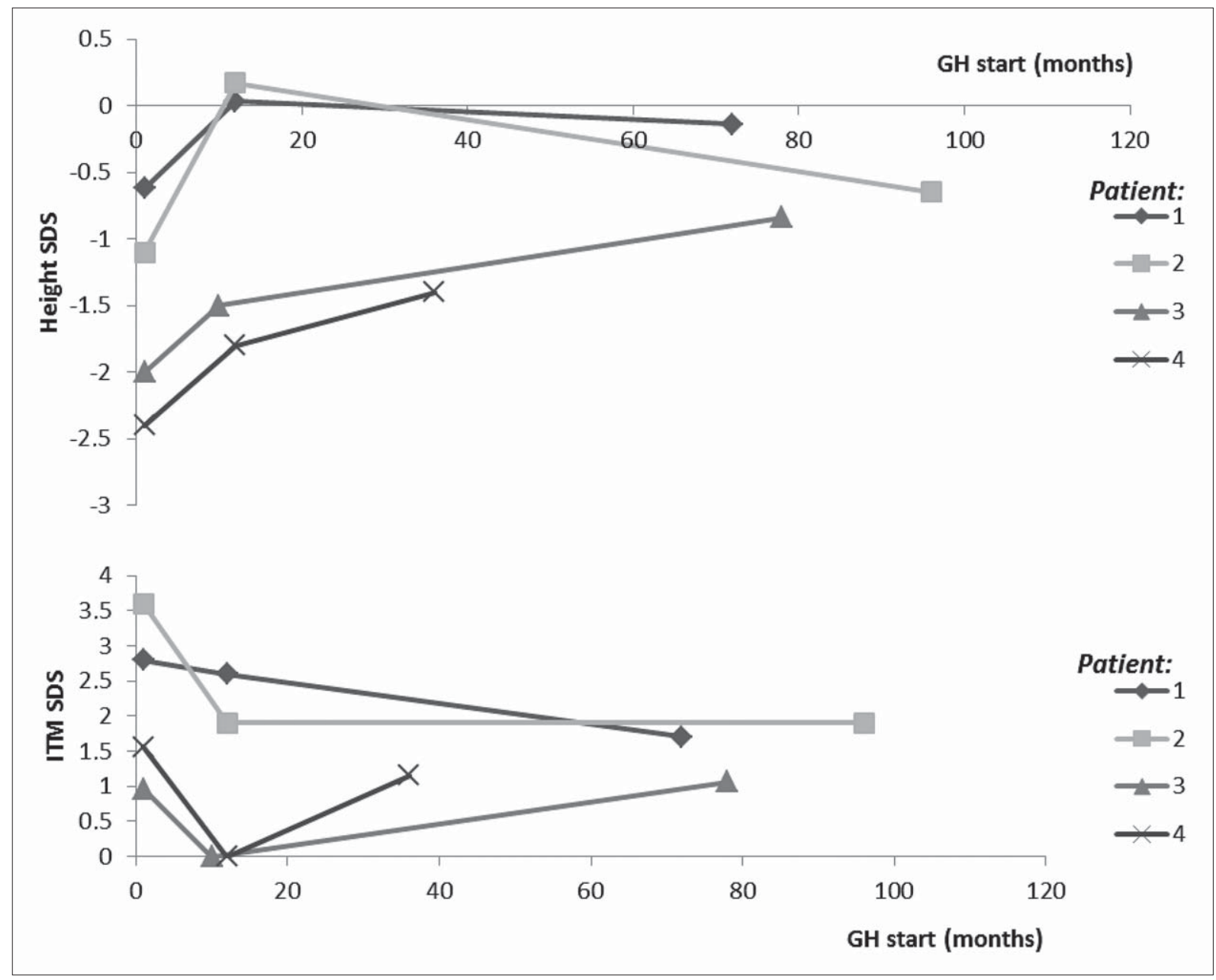

Fig. 1. Growth parameters (height SDS, BMI SDS) in PWS patients during RhGH therapy.

$\mathrm{SDS}$ = standard deviation score; $\mathrm{BMI}=$ body mass index; $\mathrm{PWS}=$ Prader-Willi syndrome; $\mathrm{RhGH}=$ recombinant human growth hormone

centile. The young man who has attained his final height has BMI of $26.5 \mathrm{~kg} / \mathrm{m}^{2} 95.7$ c, 1.7 SDS (Fig. 1, Table 1).

In all children, the planned initial dose of $\mathrm{rhGH}$ was $1 \mathrm{mg} / \mathrm{m}^{2}$, i.e. $35 \mu \mathrm{g} / \mathrm{kg}$ body weight. The dose was gradually increased during the first few months of treatment and adjusted with IGF 1 levels, which were kept between 1 and 2 SD for chronologic age. The doses of $\mathrm{rhGH}$ were in the range of $20-35 \mu \mathrm{g} / \mathrm{kg}$ body weight.

Table 2 shows PWS children comorbidities and their metabolic status through parameters measured during rhGH therapy. Breathing problems during sleep expressed by the apnea/hypopnea index during all-night polysomnographic recording before treatment initiation were above 1 in three of four children, and the follow-up apnea/hypopnea index 3-6 months after treatment initiation was lower than the initial one in all children or $<1$. In two children, adenotonsillectomy was performed before therapy introduction. Two children developed hypothyroidism during rhGH therapy and are now on replacement therapy with levothyroxine. A low-dose ACTH test did not confirm secondary adrenal insufficiency in any of the children. All male children had unilateral or bilateral undescended testes requiring orchidopexy. At treatment initiation, as well as during the follow up, insulin, blood glucose and HOMA-IR were within the normal limits for patient age and pubertal stage of development. None of the children developed diabetes during the follow up. At the beginning of treatment, elevated low-density lipoprotein (LDL) cholesterol was 
Table 2. Metabolic status and comorbidities in children with Prader-Willi syndrome treated with recombinant human growth hormone

\begin{tabular}{|c|c|c|c|c|}
\hline Patient & 1 & 2 & 3 & 4 \\
\hline Hypogonadism & $\mathrm{RP} /+$ & $\varnothing$ & $\mathrm{EP} / \mathrm{PA}$ & PP \\
\hline Testicle retention & $\begin{array}{l}\text { +/orch } \\
\mathrm{R}\end{array}$ & \begin{tabular}{|l|} 
+/orch \\
$\mathrm{B}$
\end{tabular} & $\varnothing$ & +/orch \\
\hline Hypothyroidism & + & $\varnothing$ & $\varnothing$ & + \\
\hline Scoliosis/kyphosis & + &,+ op & $\varnothing$ & $\varnothing$ \\
\hline $\begin{array}{l}\text { Sleep breathing } \\
\text { disorders (AHI) } \\
\text { Therapy initiation } \\
\text { Follow up }\end{array}$ & $\begin{array}{l}1.95 \\
0.69\end{array}$ & $\begin{array}{l}0.52 \\
0.97\end{array}$ & $\begin{array}{l}1.4 \\
0.91\end{array}$ & $\begin{array}{l}1.41 \\
1.38\end{array}$ \\
\hline Adenotonsillectomy & + & + & $\varnothing$ & $\varnothing$ \\
\hline $\begin{array}{l}\text { Fasting plasma } \\
\text { glucose (mmol/L) } \\
\text { Therapy initiation } \\
\text { Currently }\end{array}$ & $\begin{array}{l}3.9 \\
4.7\end{array}$ & $\begin{array}{l}3.5 \\
4.7\end{array}$ & $\begin{array}{l}4.8 \\
4.8 \\
\end{array}$ & $\begin{array}{l}3.7 \\
3.5\end{array}$ \\
\hline $\begin{array}{l}\text { Fasting insulin level } \\
\text { (mIU/L) } \\
\text { Therapy initiation } \\
\text { Currently }\end{array}$ & $\begin{array}{l}2.79 \\
8.5\end{array}$ & $\begin{array}{l}5.82 \\
14.7\end{array}$ & $\begin{array}{l}2.0 \\
7.2\end{array}$ & $\begin{array}{l}4.2 \\
4.3\end{array}$ \\
\hline $\begin{array}{l}\text { HOMA-IR } \\
\text { Therapy initiation } \\
\text { Currently }\end{array}$ & $\begin{array}{l}0.27 \\
1.42 \\
\end{array}$ & $\begin{array}{l}0.67 \\
2.49\end{array}$ & $\begin{array}{l}0.36 \\
1.53\end{array}$ & $\begin{array}{l}0.53 \\
0.53\end{array}$ \\
\hline $\begin{array}{l}\text { Lipid profile, LDL } \\
\text { cholesterol } \\
\text { (mmol/L) } \\
\text { Therapy initiation } \\
\text { Currently }\end{array}$ & $\begin{array}{l}3.2 \\
2.9\end{array}$ & $\begin{array}{l}2.1 \\
2.2\end{array}$ & $\begin{array}{l}2.5 \\
2.2\end{array}$ & $\begin{array}{l}3.9 \\
3.1\end{array}$ \\
\hline
\end{tabular}

$\mathrm{EP}=$ early puberty; $\mathrm{PP}$ = prepuberty $\mathrm{PA}=$ premature adrenarche; $\mathrm{AHI}=$ apnea/hypopnea index; HOMA-IR = homeostatic model assessment of insulin resistance; $\mathrm{op}=$ operation; orch $=$ orchidopexy; orch $\mathrm{R}$ = right orchidopexy; orch $\mathrm{B}$ = bilateral orchidopexy

found in two children, but improved during therapy. In the other two patients, LDL cholesterol was within the normal range during the course of treatment. During rhGH therapy, no serious side effects (malignant disease, pseudotumor cerebri, slipped capital femoral epiphysis, sleep apnea disorder) and no fatal outcomes were recorded.

\section{Discussion}

In our patients, rhGH therapy was confirmed to have a positive effect on the growth rate and consequently on the final height and BMI achieved, thereby changing the natural course of the anthropometric features in PWS. Despite the improvement in height, the patient who attained his final height did not achieve his genetic potential by reaching the midparental height. It may have been due to the fact that in his case, the treatment started relatively late, at the age of 10.5 years, and was compromised by early puberty. The positive effect on BMI was the result of both height increase with rhGH therapy, as well as early genetic confirmation of the disease, which was in most of our patients performed in the first year of life. This enabled the families to focus on the importance of an appropriate diet for PWS patients, characterized by a limited energy intake with a macronutrient ratio in which carbohydrates account for $45 \%$, proteins for $25 \%$ and fats for $30 \%$ of the daily energy inake ${ }^{17}$.

Research results showed that $\mathrm{rhGH}$ therapy in children with PWS lasting for years had a positive effect on several parameters. Therapy with rhGH accelerated growth and improved and often normalized the final height. The effect on muscle and fat tissue improved body composition, muscle strength, motor development and cognitive abilities in infants and children, as well as bone mineral density and lipid profile ${ }^{18-22}$. After almost 8 years of rhGH therapy, the final height in women increased by $14 \mathrm{~cm}$ and in men by $17 \mathrm{~cm}$ in comparison to untreated patients ${ }^{23}$. In a study by Dutch authors, the amount of muscle tissue increased significantly in the first year of treatment with rhGH and remained above the baseline for the next 7 years. Unfortunately, the portion of fatty tissue increased again after a significant fall in the first year of therapy. It was explained by the natural course of PWS, which cannot be completely altered by $\mathrm{rhGH}^{18}$. RhGH therapy administered for several years maintains BMI SDS in the reference range for the general population, significantly improving it compared to that of untreated PWS patients, which is a great success for this group of patients ${ }^{18,21}$. Two of our patients were severely obese at treatment initiation, with BMI SDS of 2.8 and 3.6 (>99 c), respectively, and 6 and 8 years of treatment resulted in a fall of BMI SDS to 1.7 and 1.9 , respectively. One child was of normal weight before therapy initiation and stayed so after 6.5 years of treatment (Table 1, Fig. 1).

With the change in body composition, primarily by the increase in muscle mass, a positive effect of $\mathrm{rhGH}$ on muscle strength was also noted, along with the con- 
sequently increased physical activity. RhGH therapy significantly reduces the retention of visceral fatty tissue, an effect which disappears when therapy is discontinued ${ }^{24}$.

During rhGH therapy, there were also improvements in motor and cognitive development. Results of a randomized controlled study indicate that long-term rhGH therapy significantly improves verbal abilities, as well as visuospatial orientation. IQs were also increased, but not at the level of significance ${ }^{25}$. The mechanism that contributes to such a positive outcome lies in the action (effect) of rhGH on brain development, as indicated by an increase in head circumference. It is clear that greater motor activity of the child owing to better muscular tone and strength contributes to the education process and thus aids cognitive development ${ }^{22,26,27}$. The role of $\mathrm{rhGH}$ and IGF in the development of cognitive functions requires further research. Current data indicate that rhGH therapy will not normalize cognitive abilities, but will improve them and thereby reduce the difference between affected children and their healthy peers ${ }^{28}$.

Therefore, the goal of rhGH therapy in children with PWS is different from that in other states of hyposomatotropism. Its aim is not only to increase the growth rate and final height, but also to improve body composition and increase body activity, thereby ultimately contributing to obesity prevention.

Soon after the introduction of rhGH therapy in children with PWS, sudden death outcomes were reported, occurring most frequently in the early stages of treatment ${ }^{29}$. Investigating the causes of death in 64 individuals with PWS, the French authors stated that $44 \%$ of the patients had been treated with $\mathrm{rhGH}$ at the time of death. Regardless of whether they were treated with rhGH or not, the most common cause of death was a respiratory system disorder, respiratory insufficiency or infection. Seventy-five percent of death outcomes occurred in the first 9 months of treatment ${ }^{30}$. Several possible mechanisms of sudden death during treatment were considered. According to the first, rhGH promotes hypertrophy of tonsillar and surrounding soft tissue, causing obstructive sleep apnea. According to the second, an increase in the basal metabolic rate causes higher oxygen requirements that cannot be met, whereas the third mechanism involves increased hydration due to water retention, which can result in heart volume overload ${ }^{31}$. Of the three theories mentioned above, most attention was paid to the one pointing to sleep disturbance disorders due to tonsillar tissue hypertrophy, which is why otorhinolaryngologic examination and polysomnographic recording should be performed before rhGH therapy introduction. $\mathrm{Pa}$ tients with PWS often suffer not only from obstructive but also from central sleep apnea. The contributing factors are obesity, restrictive pulmonary disease due to muscular weakness and scoliosis, as well as reduced response to hypercapnia and hypoxia during sleep ${ }^{6}$. Studies have confirmed that high baseline AHI caused by both obstructive and central sleep apnea remained the same or improved after rhGH therapy introduction $^{32}$, primarily owing to a decreased number of central sleep apnea episodes ${ }^{33}$. Recent studies also confirm that after 2 years of $\mathrm{rhGH}$ treatment, no significant changes in sleep disorders occurred ${ }^{34}$.

Comparing the size of tonsillar tissue prior to rhGH introduction and 4 years later, Berini et al. report an increase in primarily adenoid tissue, which required cessation of therapy due to breathing disorders $^{35}$. In healthy children and those with PWS, adenotonsillectomy is the procedure of choice in treating obstructive sleep apnea. If disturbances are continued after the procedure, the use of continous positive airway presssure (CPAP) must be considered ${ }^{36}$.

Breathing disturbances during sleep are characteristic for PWS and there is no definite evidence that $\mathrm{rhGH}$ therapy introduction increases the risk of such events in most patients, but caution and appropriate preparation before therapy initiation, and especially during the first year of treatment, are needed. For the purpose of assessing sleep disorders before the introduction of rhGH therapy, it is necessary to perform otorhinolaryngologic examination and to consider the necessity of adenotonsillectomy. Polysomnographic recording is also required in all patients. Significant sleep disorders should be treated prior to the introduction of rhGH therapy and repeat polysomnographic recording is recommended at 3-6 months after rhGH therapy introduction ${ }^{12}$. Two of our patients underwent adenotonsillectomy before rhGH therapy initiation. Polysomnography determined that the baseline frequency of AHI was not a contraindication for therapy introduction, as follow up values were also good. During the described treatment, neither adverse effects nor lethal oucomes occurred. 
Sudden death in PWS patients occurs in all age groups irrespective of rhGH therapy. In the age group up to 5 years, the most common causes are respiratory infections, and male children with a higher BMI are more vulnerable. In adolescence, as well as in adulthood, death outcomes are primarily a consequence of obesity-associated complications ${ }^{30,31}$.

In addition to unresolved obstructive sleep disorder, contraindications for the introduction of $\mathrm{rhGH}$ therapy in children include severe obesity, poorly controlled diabetes, acute malignant disease and psychosis. For children, there is no simple determinant for severe obesity, such as the one in adults of BMI $>40 \mathrm{~kg} / \mathrm{m}^{2}$, but it is defined by BMI above $99^{\text {th }}$ percentile for age and gender associated with complications such as sleep disorder, carbohydrate metabolism disorders or nonalcoholic fatty liver disease ${ }^{12}$. At the time of therapy initiation, two of our children had BMI $>99 \mathrm{c}$, but without any additional comorbidities.

During rhGH therapy, special importance is given to IGF 1 levels because of the potential effect on the development of sleep disorders and malignancies. After 24 months of rhGH treatment, in $72 \%$ of PWS children the level of IGF 1 was above 2 SD despite the fact that the rhGH dose was lower than that used for $\mathrm{GH}$ deficiency ${ }^{37}$. Until now, the increased sensitivity of patients to $\mathrm{GH}$ has not been clarified, but it is encouraging that the IGF 1 ratio and insulin-like growth factor-binding protein 3 (IGFBP 3) remain unchanged, leading to the conclusion that the level of bioavailable IGF 1 is the same as in other GH deficiencies ${ }^{7}$. Additionally, a recent study suggests that the level of immunoreactive IGF 1 is not equal to bioactive IGF 1 during rhGH therapy, and that thus immunoreactive IGF 1 is not a true marker for titration of rhGH doses in PWS patients ${ }^{38}$. RhGH therapy should be carried out with IGF 1 monitoring every 6 to 12 months to maintain its level between $1-2 \mathrm{SD}$ in order to avoid side effects ${ }^{12}$. The efficacy of a rhGH dose of $<1 \mathrm{mg} / \mathrm{m}^{2} /$ day administered for a longer period is not known, but there are indications that the positive effect on body composition gets weaker ${ }^{21}$. In our patients, with IGF 1 level monitoring, the dose of $\mathrm{rhGH}$ was $20-35 \mu \mathrm{g} / \mathrm{kg}$ body weight.

The optimal time to introduce rhGH therapy is not defined, but experts claim that therapy should be started before obesity develops, at around 2 years of age. According to the recommendations, the starting dose is 0.5 $\mathrm{mg} / \mathrm{m}^{2} /$ day with gradual increase to $1 \mathrm{mg} / \mathrm{m}^{2} /$ day, as this dose provides positive effect not only on growth but also on body composition ${ }^{12}$. Today, there is enough evidence to support early treatment, so that in some centres it begins as early as the first months of life. Currently there are data on the final height achieved by children treated with rhGH from infancy ${ }^{10}$.

Financial constraints in many environments including ours, and considerations related to breathing disorders that occur more often at an early age, lead to very different approaches in relation to patient age at therapy initiation. Since this is a presentation of the first patients in whom we applied rhGH treatment, therapy was introduced between 2.8 and 10.5 years of age. Thirty to eighty percent of patients with PWS have scoliosis, with hypotonia contributing to it. Scoliosis is not a contraindication for the introduction or continuation of rhGH therapy. It is recommended that orthopedic examination and, if necessary, spine $\mathrm{x}$-ray be performed before the therapy is started ${ }^{12}$. Two of our patients had scoliosis at the beginning of treatment. In one of them, the progression of scoliosis required surgical correction that was successfully performed.

One of the possible adverse effects of $\mathrm{rhGH}$ is a carbohydrate metabolism disorder due to insulin resistance stimulation. Therefore, during therapy, fasting plasma glucose and fasting insulin levels are monitored, as well as the levels of $\mathrm{HbA}_{1 \mathrm{c}}$, and an oral glucose tolerance test is recommended in obese children older than 12 years with a positive family history of diabetes $^{12}$. If lipid profile dysfunction develops in PWS patients, it is consistent with the one seen in GH deficiency and includes elevated levels of total and LDL cholesterol and triglycerides, accompanied by a decreased level of high-density lipoprotein (HDL) cholesterol. RhGH therapy can positively affect the levels of LDL and HDL cholesterol ${ }^{13}$. In our patients, there were no disorders of carbohydrate metabolism, and two children had elevated levels of LDL cholesterol at the beginning of treatment. There were no indications of a negative effect of $\mathrm{rhGH}$ on glucose or lipid metabolism parameters. According to other authors as well, therapy lasting for up to 8 years did not have negative effect on carbohydrate and lipid metabolism, blood pressure or progression of bone age ${ }^{18}$.

Due to hypothalamic dysfunction, in patients with PWS, central insufficiency of adrenal gland develops, 
as confirmed in 14\%-60\% of patients depending on the stimulation test used ${ }^{6,21}$. We used a low-dose $\mathrm{ACTH}$ test and did not establish cortisol or ACTH deficiency in our patients.

In all boys, unilateral or bilateral undescended testes were present, and orchidopexy was performed. During therapy, two patients entered puberty spontaneously, and one of them had an early onset of puberty. In one of them, complete progression of puberty has not occurred and hormone replacement therapy will be necessary. Individuals with PWS are almost regularly hypogonadal with delayed or incomplete puberty and infertility. Unilateral or bilateral cryptorchism is present in $80 \%-90 \%$ of boys and surgical treatment is required in the first or second year of life ${ }^{7}$. Hypogonadism is primarily associated with hypothalamic dysfunction, but today there is growing evidence for primary gonadal damage as well ${ }^{39}$.

Central hypothyroidism is recorded in approximately $25 \%$ of PWS children. There is a recommendation to start screening for hypothyroidism by measuring $\mathrm{fT} 4$ and TSH from the age of 3 months despite negative neonatal screening results, and then continue annual check-ups, especially in patients on $\mathrm{rhGH}$ therapy. In case hypothyroidism develops, levothyroxine therapy is introduced, which was also necessary in two of our patients ${ }^{6}$.

The positive effect of rhGH therapy applied in childhood is reflected in adulthood as well, even years of its cessation after growth has been completed. The effect is visible in lower BMI, as well as better body composition and metabolic status ${ }^{40}$.

The role of rhGH therapy in adult PWS patients is currently not clearly defined. According to different studies, $\mathrm{GH}$ deficiency is present in $15 \%-95 \%$ of the affected, depending on the pharmacological GH stimulation test used and the agreed level of $\mathrm{GH}$ that defines $\mathrm{GH}$ deficiency. It is therefore mandatory in many countries to assess GH secretion before the introduction of $\mathrm{rhGH}$ therapy ${ }^{6,12}$. In adults, therapeutic dose of $\mathrm{rhGH}$ for this group of patients is $0.1-0.2 \mathrm{mg} /$ day with maintenance of IGF 1 between 0 and 2 SD, as well as monitoring of the clinical response and possible adverse effects ${ }^{12}$. A meta-analysis of 8 studies evaluating the effect of $\mathrm{rhGH}$ on the body composition in adults with PWS has reported a reduction of fat tissue mass, visceral and subcutaneous fat, and an increase in muscle tissue volume. Individuals treated for 12 months experienced a mild increase in fasting blood glucose ${ }^{41}$.

\section{Conclusion}

Until recently, life expectancy in individuals with PWS was significantly reduced. Lethal outcomes at the end of the second decade od life were common, primarily due to obesity-associated complications. A significantly earlier detection of the disease by means of genetic analysis has enabled the introduction of timely changes in the eating habits of those affected, which, along with rhGH therapy, has prolonged life expectancy and improved the quality of life in most patients.

Therapy implemented until now, including a customized diet for PWS, as well as rhGH therapy, has not only provided a satisfactory growth rate in our patients, but also prevented development of morbid obesity, without any adverse effects. This treatment approach will ensure transition of a greater number of PWS patients into adult (internal medicine) care, where a multidisciplinary approach in the treatment and care of this patient population needs to be continued.

\section{References}

1. Prader A, Labhart A, Willi H. Ein Syndrom von Adipositas, Klainwuchs, Kryptorchismus und Oligophrenie nach myatonieartigen Zustand im Neugeborenenalter. Schweiz Med Wochenschr 1956;6:1260-61. https://doi.org/10.1007/978-3642-47669-3_24 (in German)

2. Nicholls RD, Knepper JL. Genome organization, function, and imprinting in Prader-Willi and Angelman syndromes. Annu Rev Genomics Hum Genet. 2001;34:917-23. http://dx.doi. org/10.1146/annurev.genom.2.1.153

3. Cassidy SB, Driscoll DJ. Parder-Willi syndrome. Eur J Hum Genet 2009;17(1):3-13. https://doi.org/10.1038/ejhg.2008.165

4. Copet P, Jauregi J, Laurier V, Ehlinger V, Arnaud C, Cobo AM, et al. Cognitive profile in large French cohort of adults with Prader Willi syndrome: differences between genotypes. J Intellect Disabil Res. 2010;54:204-15. https://doi.org/10.1111/j.1365-2788.2010.01251.x

5. Hurren BJ, Flack NAMS. Prader-Willi syndrome: a spectrum of anatomical and clinical features. Clin Anat. 2016;29: 590-605. https://doi: 10.1002/ca.22686

6. Emerick JE, Vogt KS. Endocrine manifestation and management of Prader-Willi syndrome. Int J Pediatr Endocrinol. 2013;1:14. https://doi.org/10.1186/1687-9856-2013-14 
7. Cassidy SB, Schwartz S, Miller JL, Driscoll DJ. Prader-Willi syndrome. Genet Med. 2012;14(1):10-26. https://doi.org/10.1038/gim.0b013e31822bead0

8. Butler MG, Manzardo AM, Forster JL. Prader-Willi syndrome: clinical genetics and diagnostic aspects with treatment approaches. Curr Pediatr Rev. 2016;12(2):136-66. https://doi. org/10.2174/1573396312666151123115250

9. Whittington JE, Holland AJ, Webb T, Butler J, Clarke D, Boer H. Population prevalence and estimated birth incidence and mortality rate for people with Prader-Willi syndrome in one UK Health Region. J Med Genet. 2001;38:792-8. https://doi. org/10.1136/jmg38.11.792

10. Bridges N. What is the value of growth hormone therapy in Prader Willi syndrome. Arch Dis Child. 2014;99:166-70. https://doi.org/10.1136/archdischild-2013-303760

11. Wollmann HA, Schultz U, Grauer M, Ranke MB. Reference values for height and weight in Prader Willi syndrome based on 315 patients. Eur J Pediatr. 1998;157:634-42. http://dx.doi. org/10.1007/s004310050901

12. Deal CL, Tony M, Hoybye C, Allen DB, Tauber M, Christiansen JS. Growth Hormone Research Society Workshop summary: Consensus guidelines for recombinant human growth hormone therapy in Prader-Willi syndrome. J Clin Endorinol Metab. 2013;98(6):E1072-87. https://doi.org/10.1210/jc.2012-3888

13. Carrel A, Allen D, Myers S, Whitman B. Growth hormone improves body composition, fat utilization, physical strength and agility, and growth in Prader-Willi syndrome: a controlled study. J Pediatr. 1999 Feb;134(2):215-21.

https://doi.org/10.1016/s0022-3476(99)70418-x

14. Ritzen EM, Lindgren AC, Hagenas L, Marcus C, Muller J, Blichfeldt S, Swedish Growth Hormone Advisory Group. Growth hormone treatment of patients with Prader-Willi syndrome.J Pediatr Endocrinol Metab. 1999;12:345-9. https:// www.ncbi.nlm.nih.gov/pubmed/?term=Growth+hormone+tre atment+of+patients+with+Prader-Willi+syndrome.+J+Pediatr +Endocrinol+Metab+1999\%3B12\%3A345-9

15. CDC, National Center for Health Statistics, Department of Health and Human Services. 2000 CDC Growth Charts for United States: Methods and Development. Vital and Health Statistics, Series 11, Number 246, May 2002. https://www.cdc. gov/growthcharts/cdc_charts.htm

16. Tanner JM, Whitehouse RH. Clinical longitudinal standards for height, weight, height velocity, weight velocity and stages of puberty. Arch Dis Child. 1976;51:170-9. http://dx.doi.org/10.1136/adc.51.3.170

17. Miller JL, Lynn CH, Shuster J, Driscoll DJ. A reduced-energy intake, well-balanced diet improves weight control in children with Prader-Willi syndrome. J Hum Nutr Diet. 2013;26:2-9. https://doi.org/10.1111/j.1365-277x.2012.01275.x

18. Bakker NE, Kuppens RJ, Siemensma EPC, Tummers-de Lind van Wijngaarden RFA, Festen DAM, Bindels-de Heus GCB, et al. Eight years of growth hormone treatment in children with Prader-Willi syndrome: maintaining the positive effects. J Clin
Endocrinol Metab. 2013;98:4013-22. https://doi.org/10.1210/ jc. 2013-2012

19. Meinhardt U, Christiansen JS, Farholt S, Lammer C, Ostergaard JR, Schmidt F, et al. The efficacy and safety of long-term Norditropin treatment in children with Prader-Willi syndrome. Horm Metab Res. 2013;45:532-6. https://doi.org/ 10.1055/s-0033-1343449

20. Carrel AL, Myers SE, Whitman BY, Eickhoff J, Allen DB. Long-term growth hormone therapy changes the natural history of body composition and motor function in children with Prader-Willi syndrome. J Clin Endocrinol Metab. 2010;95: 1131-6. https://doi.org/ 10.1210/jc.2009-1389

21. de Lind van Wijngaarden RF, Siemensma EP, Festen DA, Otten BJ, van Mil EG, Rotteveel J, et al. Efficacy and safety of long-term continuous growth hormone treatment in children with Prader-Willi syndrome. J Clin Endocrinol Metab. 2009 Nov;94(11):4205-15. https://doi.org/10.1210/jc.2007-2294

22. Festen DA, Wevers M, Lindgren AC, Bohm B, Otten BJ, Wit $\mathrm{JM}$, et al. Mental and motor development before and during growth hormone treatment in infants and toddlers with Prader-Willi syndrome. Clin Endocrinol. 2008;68(6):919-25. http://dx.doi.org/10.1111/j.1365-2265.2007.03126.x

23. Angulo MA, Castro-Magana M, Lamerson M, Arquello R, Accacha S, Khan A. Final adult height in children with Prader Willi syndrome with and without human growth hormone treatment. Am J Med Genet. 2007;143A:1456-61.

https://doi.org/10.1002/ajmg.a.31824

24. Tanaka Y, Abe Y, Oto Y, Itabashi H, Shiraishi M, Yoshino A, et al. Characterization of fat distribution in Prader-Willi syndrome: relationship with adipocytokines and influence of growth hormone treatment. Am J Med Genet Part A. 2013; 161:27-33. https://doi.org/10.1002/ajmg.a.35653

25. Siemensma EP, Tummers-de Lind van Wijngaarden RF, Festen DA, Troeman ZC, van Alfen-van der Velden AA, Otten BJ, et al. Beneficial effects of growth hormone treatment on cognition in children with Prader-Willi syndrome: a randomized controlled trial and longitudinal study. J Clin Endocrinol Metab. 2012; 97(7):2307-14. https://doi.org/10.1210/jc.2011-1954

26. Myers SE, Whitman BY, Carrel AL, Moecher V, Bekx MT, Allan DB. Two years of growth hormone therapy in young children with Prader-Willi syndrome: physical and neurodevelopmental benefits. Am J Med Genet Part A. 2007;143 (5):443-8. DOI: 10.1002/ajmg.a.31468

27. Nugnes R, Zito E, Mozzillo E, Camarca ME, Riccio MP, Terrone $\mathrm{G}$, et al. Good cognitive performance in a child with Prader-Willi syndrome. Int J Pediatr Endocrinol.2013;1:14. https:// doi.org/10.1186/1824-7288-39-74.

28. Wolfgram PM, Carrel AL, Allen DB. Long-term effects of recombinant human growth hormone therapy in children with Prader-Willi syndrome. Curr Opin Pediatr. 2013;25(4): 509-14. https://doi.org/10.1097/MOP.0b013e328362c7a2

29. Einholzer U, Nordmann Y, L'Allemand D. Fatal outcome of sleep apnea in PWS during the initial phase of growth hor- 
mone treatment. A case report. Horm Res. 2002;58(Suppl 3): 24-6. https://doi.org/10.1159/000066478

30. Tauber M, Diene G, Molinas C, Hebert M. Review of 64 cases of death in children with Prader-Willi syndrome (PWS). Am J Med Genet Part A. 2008;146A:881-7. https://doi.org/10.1002/ajmg.a.32131

31. Whitman BY, Myers SE. Prader-Willi syndrome and growth hormone therapy: take a deep breath and weigh the data. J Pediatr. 2013;162:224-6. https://doi.org/10.1136/jmg.38.11.792

32. Festen DA, de Weerd AW, van den Bossche RA, Joosten K, Hoeve H, Hokken-Koelege ACS. Sleep-related breathing disorder in prepubertal children with Prader-Willi syndrome and the effects of growth hormone treatment. J Clin Endocrinol Metab. 2006;91:4911-5. https://doi.org/10.1210/jc.2006-0765

33. Miller JL, Silverstein JH, Shuster J, Driscol DJ, Wagner M. Short-term effects of growth hormone on sleep abnormalities in Prader-Willi syndrome. J Clin Endocrinol Metab. 2006; 91:4911-5. http://dx.doi.org/10.1210/jc.2005-1279

34. Al-Saleh S, Al-Naimi A, Hamilton J, Zweerink A, Iaboni A, Narang I. Longitudinal evaluation of sleep-disordered breathing in children with Prader-Willi syndrome during 2 years of growth hormone therapy. J Pediatr. 2013 Feb;162(2):263-8. https://doi.org/10.1016/j.jpeds.2012.07.042

35. Berini J, Spica Russotto V, Castelnuovo P, Di Candia S, Gargantini L, Grugni G, et al.; Genetic Obesity Study Group of the Italian Society of Pediatric Endocrinology and Diabetology (ISPED). Growth hormone therapy and respiratory disorders: long-term follow-up in PWS children. J Clin Endocrinol Matab. 2013;98(9):E1516-23.

https://doi.org/10.1210/jc.2013-1831.
36. Angulo MA, Butler MG, Cataletto ME. Prader-Willi syndrome: a review of clinical, genetic and endocrine findings. J Endocrinol Invest. 2015;38:1249-63. https://doi.org/10.1007/s40618-015-0312-9

37. Feigerlová E, Diene G, Oliver I, Gennero I, Salles JP, Arnaud $\mathrm{C}$, et al. Elevated insulin-like growth factor-1 values in children with Prader-Willi syndrome compared with growth hormone (GH) deficiency children over two years of GH treatment. J Clin Endocrinol Metab. 2010;95:4600-8. https://doi.org./10.1210/jc.2009-1831

38. Bakker NE, van Doorn J, Renes JS, Donker GH, HokkenKoelega AC. IGF-1 levels, complex formation, and IGF bioactivity in growth hormone-treated children with Prader-Willi syndrome. J Clin Endocrinol Metab. 2015;100(8):3041-9. https://doi.org/10.1210/jc.2015-1410

39. Siemensma EP, de Lind van Wijngaarden RF, Otten BJ, de Jang FH, Hokken-Koelega AC. Testicular failure in boys with Prader-Willi syndrome: longitudinal studies of reproductive hormones. J Clin Endocrinol Metab. 2012;97(3):E452-9. https://doi.org/10.1210/jc.2011-1954

40. Coupaye M, Lorenzini F, Lloret-Linares C, Molinas C, Pinto $\mathrm{G}$, Diene $\mathrm{G}$, et al. Growth hormone therapy for children and adolescents with Prader-Willi syndrome is associated with improved body composition and metabolic status in adulthood. J Clin Endocrinol Metab. 2013;98(2):E328-35. https://doi.org/10.1210/jc.2012-2881

41. Sanchez-Ortiga R, Klibanski A, Tritos NA. Effects of recombinant human growth hormone therapy in adults with PraderWilli syndrome: a meta-analysis. Clin Endocrinol (Oxf). 2012 Jul;77(1):86-93.

https://doi.org/10.1111/j.1365-2265.2011.04303.x 
Sažetak

\title{
UČINAK TERAPIJE HORMONOM RASTA U DJECE S PRADER-WILLIJEVIM SINDROMOM - PRVA VLASTITA ISKUSTVA
}

\author{
G. Stipančić, M. Požgaj Šepec i L. La Grasta Sabolić
}

Prader-Willijev sindrom (PWS) najčešći je uzrok teške debljine u dječjoj dobi. Posljedica je izostanka ekspresije očevih gena u regiji 15q11.2-q13. Kliničkom slikom dominira hiperfagija, debljina, nizak rast, psihomotoričko zaostajanje i poremećaji ponašanja. Terapija rekombinantnim humanim HR (rhHR) postala je, uz ograničenje energetskog unosa, imperativ u zbrinjavanju bolesnika s PWS-om. U 4 djece s PWS-om koja su $\geq 2$ godine liječena $\mathrm{rhHR}$ u dozi do $1 \mathrm{mg} / \mathrm{m}^{2} /$ dan pratili smo antropometrijske parametre, tjelesnu visinu (TV) i indeks tjelesne mase (ITM) te učinak terapije na metabolizam ugljikohidrata, lipida i pojavu neželjenih učinaka. Uz primjenu rhHR je TV standard deviation score (SDS) bio u porastu u odnosu na početnu vrijednost i nakon $\geq 2$ godine liječenja bio je unutar referentnog raspona za opću dječju populaciju. ITM SDS snizio se nakon prve godine liječenja, potom je bio u porastu, ali je i nadalje razina bila bolja nego u većine djece u populaciji s PWS-om. Terapija rhHR-om nije nepovoljno utjecala na metabolizam glukoze i lipida te nije izazvala neželjenih učinaka. Terapija koja uključuje prehranu prilagođenu PWS-u i rhHR-om osigurala je zadovoljavajući rast djece i spriječila razvoj teške debljine bez neželjenih učinaka. Takav pristup liječenju osigurat će tranziciju većeg broja bolesnika u internističku skrb koja treba nastaviti s multidisciplinarnim pristupom u liječenju i skrbi za ovu skupinu bolesnika.

Ključne riječi: Prader-Willijev sindrom; Pretilost, morbidna; Humani hormon rasta - terapijska primjena; Paternalno nasljedivanje; Energetski unos 